\title{
50. CHEMICAL COMPOSITION AND METAL ACCUMULATION RATES OF METALLIFEROUS SEDIMENTS FROM SITES 319, 320, AND 321
}

\author{
Jack Dymond, John B. Corliss, and Ronald Stillinger, \\ School of Oceanography, Oregon State University, Corvallis, Oregon
}

\begin{abstract}
Chemical analyses of 22 elements in 27 samples from DSDP Leg 34 cores clarify some of the sedimentological processes operating on the Nazca plate. All sediments analyzed have high transition metal to aluminum ratios typical of metalliferous sediments found near spreading centers. Distinctive compositional differences exist between surficial sediments and basal sediments of Site 319. The elemental abundance patterns and metal accumulation rate data for these two contrasting parts of the core suggest that the basal sediments are dominated by hydrothermal sources of metals, while the hydrogenous precipitation is important in the near-surface sediments. Hole 320B and Site 321 exhibit many of the same compositional patterns; however, the younger sediments of Site 321 reflect an increasingly important detrital sediment component.
\end{abstract}

\section{INTRODUCTION}

Two areas of the Nazca plate, the East Pacific Rise Crest (EPR) and the Bauer Deep, have Recent sediments with anomalously high concentrations of various transition metals. The EPR sediments have been extensively studied, and on the basis of their unique chemistry (Boström, 1973 and references contained therein), accumulation rates (Bender et al., 1971), and lead isotopic composition (Bender et al., 1971; Dymond et al., 1973), these metalliferous sediments are thought to form from hydrothermal solutions resulting from mid-ocean ridge volcanism. Sediments from the Bauer Deep have been less extensively studied than the Rise Crest sediments and their origin is less certain. Although the Bauer Deep sediments are chemically similar to EPR sediments, some clear compositional distinctions can be made (Dymond et al., 1973). In addition, the metal accumulation rates are much lower in the Bauer Deep than on the EPR crest (Dymond and Veeh, in press). Nonetheless, lead isotopic data of Bauer Deep sediments indicate a magmatic origin.

Leg 34 of the Deep Sea Drilling Project recovered sediments from three locations on the Nazca plate. These sites are located on crust formed by volcanism along the now extinct Galapagos Rise, and one of the sites (319) is within the Bauer Deep. These sites, consequently, offer the possibility of (1) looking for evidence of metalliferous sediments deposited on the Galapagos Rise; (2) comparing possible hydrothermal products in basal sediments of different ages formed on the Galapagos Rise; and (3) investigating the time variations of the composition of metalliferous sediments in the Bauer Deep over the past 16 m.y.

\section{ANALYTICAL PROCEDURES}

The chemical compositions of the sediments were determined by instrumental neutron activation (INAA) and atomic absorption spectrophotometry (AAS). All sediments were dried at $110^{\circ} \mathrm{C}$ overnight before weighing for the analysis. For the INAA analyses, the samples were irradiated with USGS standard rocks in the rotating rack of the Oregon State 1 megawatt TRIGA research reactor. The samples were counted on an $8 \%$ efficient $\mathrm{Ge}(\mathrm{Li})$ detector with $0.9 \mathrm{kev}$ resolution at $122 \mathrm{kev}$ and $2.0 \mathrm{kev}$ resolution at $1333 \mathrm{kev}$. Data accumulation and reduction were done with a computerized multichannel analyzer system. Each sample was counted twice, once 5 to 12 days after irradiation for $\mathrm{Na}, \mathrm{La}$, and $\mathrm{Sm}$ and after 18 days for the remaining elements. The general procedure is discussed in Gordon et al. (1968).

AAS measurements were made on samples dissolved in Teflon-lined bombs using $\mathrm{HF}, \mathrm{HNO}_{3}$, and $\mathrm{HCl}$ heated to $125^{\circ} \mathrm{C} . \mathrm{H}_{3} \mathrm{BO}_{3}$ was added to neutralize the $\mathrm{HF}$ and to dissolve insoluble fluorides. $\mathrm{CsCl}$ was added to both standards and unknowns to depress ionization effects caused by the presence of $\mathrm{Na}$ in the samples. Standard solutions, prepared from pure metals, were matched with respect to $p \mathrm{H}$ and anion content. The precision of these analyses varies from less than $1 \%$ for the major elements and trace elements with concentrations greater than $200 \mathrm{ppm}$ to approximately $20 \%$ for trace elements in the $\mathrm{CaCO}_{3}$-rich samples. Comparison with reported data on USGS standard rocks suggest there are no systematic errors. We have analyzed $\mathrm{Fe}$ and $\mathrm{Ba}$ by both INAA and AAS. In most cases the iron analyses agree to better than $5 \%$ and the $\mathrm{Ba}$ analyses agree to within $15 \%$.

Salt content of each sample was determined by measuring the water content of the bulk sample and assuming a constant salinity of $35 \%$ for the interstitial waters. The $\mathrm{CaCO}_{3}$ content of each sample was determined by measuring the total calcium content of the sediment and solving a mass balance equation of the form:

$$
\mathrm{Ca}_{T}=\mathrm{Ca}_{S} S+\mathrm{Ca}_{N} N+\mathrm{Ca}_{c} \mathrm{C}
$$


where:

$\mathrm{Ca}_{\mathrm{t}}=$ the wt\% of $\mathrm{Ca}$ in the total sample

$\mathrm{Ca}_{s}=$ the $\mathrm{wt} \%$ of $\mathrm{Ca}$ in the salt fraction of the sample, which equals $1.14 \%$ for sea salts

$\mathrm{S}=$ the weight fraction of salt in the sample

$\mathrm{Ca}_{N}=$ the wt $\%$ of $\mathrm{Ca}$ in the noncarbonate fraction

$\mathrm{N}=$ the weight fraction of noncarbonate phases

$\mathrm{Ca}_{c}=$ the wt\% of $\mathrm{Ca}$ in $\mathrm{CaCO}_{3}$, which equals $40.04 \%$

$\mathrm{C}=$ the weight fraction of $\mathrm{CaCO}_{3}$ in the sediment

The measured variables in this expression are $\mathrm{Ca} T$ and $S$. By definition, the sediments is composed of only salt, noncarbonate and $\mathrm{CaCO}_{3}$ phases. Therefore, $S+N+C$ $=1$, which when combined with Eq. 1 results in one equation with two unknowns, $\mathrm{Ca} N$ and $C$ :

$$
\begin{gathered}
\mathrm{Ca}_{T}=1.14 S+\mathrm{Ca}_{N}-\mathrm{Ca}_{N} S-\mathrm{Ca}_{N} C \\
+40.04 C
\end{gathered}
$$

By assuming a value for the percent $\mathrm{Ca}$ in the noncarbonate fraction $\left(\mathrm{Ca}_{N}\right)$, this equation can be solved for $C$, the percent of $\mathrm{CaCO}_{3}$. Fortunately, for the sediments of the Nazca plate, $\mathrm{Ca}$ is a relatively minor element of the noncarbonate fraction. We have measured the $\mathrm{Ca}$ content of 12 samples which had been leached with buffered acetic acid or which by visual inspection were naturally free of $\mathrm{CaCO}_{3}$. The $\mathrm{Ca}$ content of these noncarbonate samples is $0.73 \pm 0.12 \%$, and we have chosen this value for $\mathrm{Ca}_{N}$ of Eq. 2. With appropriate rearranging, the final equation results:

$$
C=\frac{{ }^{\mathrm{Ca}_{T}}-0.41 S-0.73}{39.31} \times 100
$$

Figure 1 shows the effects of errors in our assumption that $\mathrm{Ca}_{N}=0.73 \%$. It can be seen that if our estimate of $\mathrm{Ca}_{N}$ is $100 \%$ too high or low, large percentage errors in

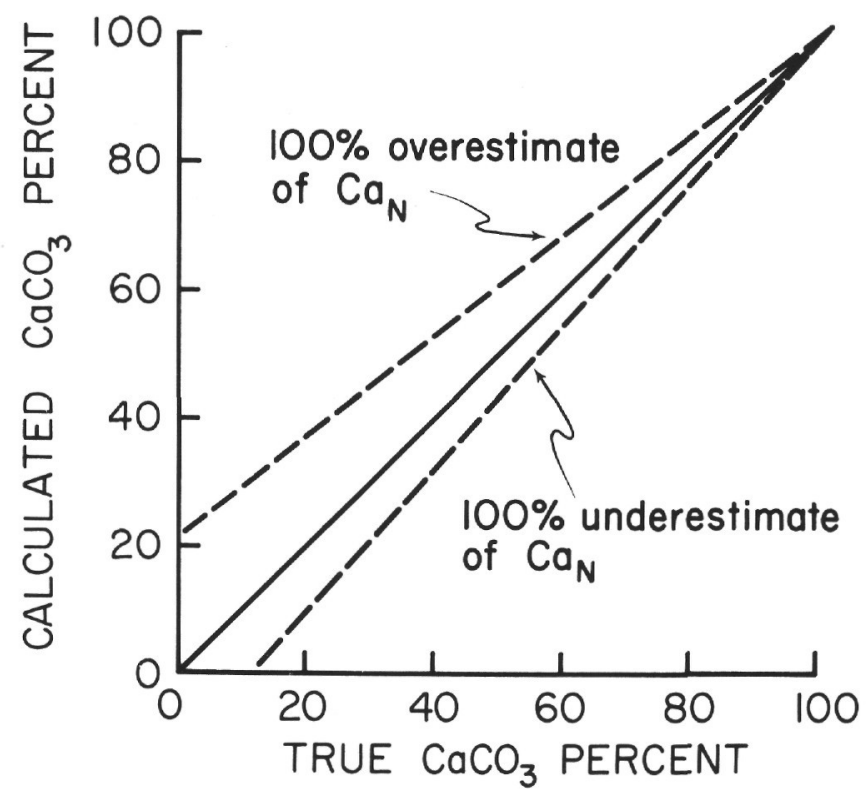

Figure 1. Errors introduced into the $\mathrm{CaCO}_{3}$ determination by errors in the estimate of $\mathrm{Ca}_{N}$ of Equation 1. our $\mathrm{CaCO}_{3}$ determination result for sediments with less than $10 \% \mathrm{CaCO}_{3}$. The important point, however, is that the errors due to poor estimates of $\mathrm{Ca}_{N}$ drop very rapidly with higher $\mathrm{CaCO}_{3}$ contents and reach values of approximately $1 \%$ in error for sediments with $90 \% \mathrm{CaCO}_{3}$. Our experience with other methods of determining $\mathrm{CaCO}_{3}$ (Leco-combustion and acid leaching) suggests that for high $\mathrm{CaCO}_{3}$ contents there may be no more accurate means of measuring $\mathrm{CaCO}_{3}$ in these sediments. It should be emphasized that as the percent of $\mathrm{CaCO}_{3}$ in a sediment approached $100 \%$, small errors in the $\mathrm{CaCO}_{3}$ are magnified greatly into the determination of the carbonate-free correction factor. Our $\mathrm{CaCO}_{3}$ estimate theoretically has the greatest precision near $100 \%$ $\mathrm{CaCO}_{3}$, and errors in the $\mathrm{Ca}_{N}$ assumption result in relatively constant errors in the carbonate-free correction factor ( $<9 \%$ error for $100 \%$ underestimate and $<5 \%$ for $100 \%$ overestimation between 10 and $100 \% \mathrm{CaCO}_{3}$ ).

\section{DATA}

Twenty-seven samples were analyzed for 22 elements (Table 1) from Leg 34 sites. At Site 319, the Bauer Deep site, samples were taken at relatively equal intervals over the entire length of the core. At Site 320 six samples spaced over the lower 50 meters of core were analyzed. Two samples, 319-1 and 319-2, included in the Site 319 data are not from the DSDP core but were sampled by

\begin{tabular}{|c|c|c|}
\hline $\begin{array}{c}\text { Sample } \\
\text { Code }\end{array}$ & Sample (Interval in $\mathrm{cm}$ ) & $\begin{array}{c}\text { Depth } \\
\text { Below } \\
\text { Ocean } \\
\text { Floor } \\
(\mathrm{m})\end{array}$ \\
\hline $319-1$ & Y73-3-13 MG3, 5-10 & 0.08 \\
\hline $319-2$ & Y73-3-13 MG3, 25-30a & 0.28 \\
\hline $319-3$ & $319-1-2,60-62$ & 2.11 \\
\hline $319-4$ & $319-1-3,80-82$ & 3.81 \\
\hline $319-5$ & $319-1-6,23-25$ & 7.74 \\
\hline $319-6$ & $319-2-4,40-42$ & 14.41 \\
\hline $319-7$ & $319-3-3,80-82$ & 22.81 \\
\hline $319-8$ & $319-4-1$ and $2,8-10,104-106$ & 30.00 \\
\hline $319-9$ & $319-5-2$ and $3,6-8,40-42$ & 40.00 \\
\hline $319-10$ & $319-6-4$ and $5,20-22,122-124$ & 53.50 \\
\hline 319-11 & $319-7-3,129-131$ & 61.30 \\
\hline $319-12$ & $319-7-6,69-71$ & 65.20 \\
\hline $319-13$ & $319-8-5,114-116$ & 73.65 \\
\hline 319-14 & $319-9-2,124-126$ & 78.75 \\
\hline $319-15$ & $319-10-2,86-88$ & 87.87 \\
\hline 319-16 & $319-11-2,80-82$ & 97.31 \\
\hline 319-17 & $319-11-5,57-59$ & 101.58 \\
\hline $319-18$ & $319-11-6,40-43$ & 102.92 \\
\hline 319-19 & $319-12-3,86-93$ & 106.89 \\
\hline $320-1$ & $320 \mathrm{~B}-2-3,140-142$ & 149.91 \\
\hline $320-2$ & $320 \mathrm{~B}-2-5,89-91$ & 152.40 \\
\hline $321-1$ & $321-9-1,30-32$ & 68.31 \\
\hline $321-2$ & $321-9-6,50-52$ & 76.01 \\
\hline $321-3$ & $321-11-2,80-82$ & 89.31 \\
\hline $321-4$ & $321-13-1,133-135$ & 116.84 \\
\hline $321-5$ & $321-13-2,84-86$ & 117.85 \\
\hline $321-6$ & $321-13-3,125-127$ & 119.76 \\
\hline
\end{tabular}

TABLE 1

Samples Analyzed

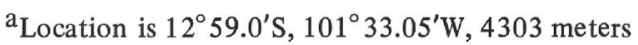
depth. 
gravity coring in the same location by an Oregon State cruise YALOC-73. These samples provide a surface sampling of the site not possible by the DSDP coring.

Metal accumulation rates (Table 2) have been calculated using the compositional data in Table 3, shipboard bulk density measurements, and paleontological age control (Quilty, this volume; Quilty et al., this volume).

\section{DISCUSSION}

We have based much of the discussion of the metalliferous sediments of this site on an acceptance of the hypothesis that a marine hydrothermal system is the essential mechanism for their formation. There are many aspects of marine hydrothermal systems which are unknown and need refinement. For example, we have only crude ideas about which elements have a magmatic source and which a seawater source; we know little about the composition of the hydrothermal fluids; and we are only beginning to understand the important rock-water reactions which produce metal enrichments in the hydrothermal fluid and change the rock compositions. Nonetheless, the chemistry of the sediments 'high transition metal to Al ratios); the high accumulaion rates of these sediments on mid-ocean ridges; the magmatic lead isotopic composition of the sediments; and geophysical data (primarily heat-flow patterns) strongly point to hydrothermal processes for their origin. Thus, for the sake of brevity, we have not considered alternative hypotheses of origin in our discussion (low temperature weathering for example).

\section{Hole 319}

\section{Chemical Composition}

Compared to typical pelagic sediments, the chemical composition of the sediments analyzed in this study are anomalous with regard to their unusually low aluminum and high iron values (Figure 2). However, the sediments from Site 319 are very similar to other metalliferous sediments in surface samples from the Nazca plate (Figures 2 and 3). The upper 20 meters of Hole 319 are similar to surficial Bauer Deep sediments, while the basal sediments strongly resemble surficial EPR sediments (Figures 2 and 3). The elements $\mathrm{Ca}, \mathrm{Zn}, \mathrm{Mn}$, and $\mathrm{Fe}$ are strongly correlated with each other and in general have the highest abundances in the basal sediments (Figure 4). Since the bottom 40 meters of the core were deposited between 16 to 13 m.y. ago as this site was near the crest of the Galapagos Rise, it is tempting to ascribe the origin of these elements primarily to

TABLE 2

Metal Accumulation Rates

\begin{tabular}{|c|c|c|c|c|c|c|c|}
\hline \multirow[b]{2}{*}{ Sample } & \multirow{2}{*}{$\begin{array}{c}\text { Sedimentation } \\
\text { Rate }^{\mathrm{a}} \\
\left(\mathrm{cm} / 10^{3} \mathrm{yr}\right)\end{array}$} & \multirow{2}{*}{$\begin{array}{c}\text { Density }^{b} \\
(g / c c)\end{array}$} & \multirow[b]{2}{*}{$\mathrm{Fe}$} & \multicolumn{3}{|c|}{$\begin{array}{l}\text { Accumulation Rates } \\
\left(\mathrm{mg} / \mathrm{cm}^{2} / 10^{3} \mathrm{yr}\right)\end{array}$} & \multirow[b]{2}{*}{$\mathrm{Ni}$} \\
\hline & & & & $\mathrm{Mn}$ & $\mathrm{Si}$ & $\mathrm{Al}$ & \\
\hline $319-1$ & 0.11 & 1.14 & 2.9 & 0.86 & 3.1 & 0.64 & 0.022 \\
\hline $319-2$ & 0.11 & 1.15 & 3.0 & 1.1 & 3.2 & 0.58 & 0.021 \\
\hline $319-3$ & 0.11 & 0.18 & 3.5 & 1.2 & 3.8 & 0.73 & 0.019 \\
\hline $319-4$ & 0.11 & 1.17 & 3.9 & 0.92 & 4.0 & 0.65 & 0.018 \\
\hline $319-5$ & 0.11 & 1.14 & 4.0 & 0.90 & 3.8 & 0.61 & 0.015 \\
\hline $319-6$ & 0.44 & 1.32 & 13 & 2.6 & 15 & 1.0 & 0.020 \\
\hline $319-7$ & 0.44 & 1.30 & 9.2 & 2.1 & 9.2 & 0.53 & 0.012 \\
\hline $319-8$ & 0.44 & 1.56 & 16 & 3.4 & 6.2 & 1.0 & 0.021 \\
\hline $319-9$ & 3.2 & 1.62 & 32 & 7.1 & 10 & 1.8 & 0.060 \\
\hline $319-10$ & 3.2 & 1.67 & 25 & 4.8 & 10 & 1.8 & 0.059 \\
\hline $319-11$ & 3.2 & 1.69 & 52 & 12 & 20 & 3.8 & 0.089 \\
\hline $319-12$ & 3.2 & 1.68 & 34 & 7.9 & 17 & 2.6 & 0.052 \\
\hline $319-13$ & 3.2 & 1.72 & 85 & 23 & 25 & 4.7 & 0.21 \\
\hline $319-14$ & 3.2 & 1.69 & 221 & 70 & 46 & 8.3 & 0.57 \\
\hline $319-15$ & 3.2 & 1.74 & 86 & 25 & 23 & 3.7 & 0.22 \\
\hline $319-16$ & 3.2 & 1.79 & 172 & 53 & 33 & 6.0 & 0.48 \\
\hline $319-17$ & 3.2 & 1.68 & 181 & 54 & 37 & 6.4 & 0.43 \\
\hline $319-18$ & 3.2 & 1.68 & 107 & 33 & 21 & 3.4 & 0.27 \\
\hline $320-1$ & 0.67 & 1.68 & 15 & 7.0 & 8.0 & 0.78 & 0.052 \\
\hline $320-2$ & 0.67 & 1.68 & 17 & 7.9 & 8.3 & 0.82 & 0.048 \\
\hline $321-1$ & 0.28 & 1.60 & 11 & 3.2 & 18 & 6.3 & 0.050 \\
\hline $321-2$ & 0.28 & 1.63 & 29 & 6.1 & 14 & 4.7 & 0.074 \\
\hline $321-3$ & 0.62 & 1.63 & 5.5 & 1.3 & 3.5 & 1.1 & 0.017 \\
\hline $321-4$ & 0.62 & 1.67 & 22 & 12 & 6.3 & 1.8 & 0.12 \\
\hline $321-5$ & 0.62 & 1.67 & 40 & 21 & 7.2 & 1.9 & 0.20 \\
\hline $321-6$ & 0.62 & 1.67 & 23 & 5.9 & 3.8 & 6.1 & 0.077 \\
\hline
\end{tabular}

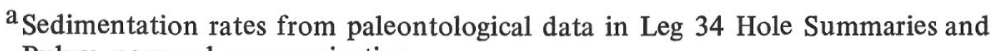
Bukry, personal communication.

${ }^{b}$ Density from data in Leg 34 Hole Summaries. In most cases these values are from measurements on nearby samples; however, in a few cases there were no measurements available for close samples. The density estimates in these cases are typical values for sediments with similar $\mathrm{CaCO}_{3}$ contents. 
TABLE 3

Carbonate and Salt Corrected Chemical Compositions

\begin{tabular}{|c|c|c|c|c|c|c|c|c|c|c|c|c|c|c|}
\hline & $319-1$ & $319-2$ & $319-3$ & $319-4$ & $319-5$ & $319-6$ & $319-7$ & $319-8$ & $319-9$ & $319-10$ & 319-11 & $319-12$ & $319-13$ & $319-14$ \\
\hline $\begin{array}{l}\text { Depth in core }(\mathrm{m}) \\
\text { Major elements }(\%)\end{array}$ & 0.08 & 0.28 & 2.11 & 3.81 & 7.74 & 14.41 & 22.81 & 30.00 & 40.00 & 53.50 & 61.30 & 65.20 & 73.65 & 78.75 \\
\hline $\mathrm{Fe}(\mathrm{AASC})$ & 16.45 & 16.68 & 16.25 & 17.50 & 18.20 & 16.86 & 17.90 & 26.00 & 21.00 & 13.50 & 18.50 & 24.20 & 26.00 & 32.30 \\
\hline $\mathrm{Fe}$ (INAA) & - & - & 18.80 & 19.30 & 21.30 & 17.30 & 20.30 & 26.00 & 22.00 & 13.90 & 18.50 & 26.70 & 30.00 & 32.10 \\
\hline $\mathrm{Mn}$ & 4.94 & 6.05 & 5.39 & 4.14 & 4.15 & 3.46 & 4.06 & 5.60 & 5.00 & 2.60 & 4.24 & 5.69 & 7.00 & 10.20 \\
\hline $\mathrm{Si}$ & 17.51 & 17.36 & 17.33 & 17.67 & 17.60 & 19.33 & 18.00 & 10.20 & 7.00 & 5.40 & 7.00 & 12.30 & 7.70 & 6.70 \\
\hline Al & 3.65 & 3.15 & 3.35 & 2.94 & 2.80 & 1.14 & 1.03 & 1.63 & 1.20 & 0.95 & 1.35 & 1.87 & 1.40 & 1.21 \\
\hline $\mathrm{Ba}$ (AASC) & 2.36 & 2.37 & 2.27 & 2.19 & 2.24 & 1.62 & 1.25 & 1.16 & 1.20 & 1.18 & 1.16 & 1.90 & 1.01 & 0.64 \\
\hline $\begin{array}{l}\text { Ba (INAA) } \\
\text { Trace elements (ppm) }\end{array}$ & - & - & 2.31 & 2.58 & 2.59 & 1.39 & 1.12 & .98 & 1.10 & 1.03 & 1.03 & 1.60 & 1.03 & 0.57 \\
\hline $\mathrm{Sc}$ & - & - & 29.30 & 25.40 & 26.30 & 10.89 & 10.70 & 11.80 & 15.00 & 10.10 & 12.30 & 19.10 & 14.00 & 9.60 \\
\hline $\mathrm{Cr}$ & - & - & 40.00 & 36.00 & 40.00 & 18.80 & 39.00 & 18.00 & - & - & 24.00 & 45.00 & 27.00 & 25.00 \\
\hline Co & - & - & 319.00 & 236.00 & 249.00 & 100.00 & 108.00 & 169.00 & 160.00 & 114.00 & 139.00 & 197.00 & 180.00 & 136.00 \\
\hline $\mathrm{Ni}$ & 1259.00 & 1161.00 & 874.00 & 797.00 & 690.00 & 261.00 & 225.00 & 350.00 & 400.00 & 310.00 & 310.00 & 570.00 & 630.00 & 830.00 \\
\hline $\mathrm{Cu}$ & 1360.00 & 1167.00 & 1172.00 & 1184.00 & 1190.80 & 1044.00 & 1220.00 & 1530.00 & 1500.00 & 1120.00 & 1210.00 & 1880.00 & 1800.00 & 1650.00 \\
\hline $\mathrm{Zn}$ & 472.50 & 503.70 & 442.00 & 450.00 & 461.00 & 418.00 & 372.00 & 500.00 & 600.00 & 363.00 & 380.00 & 540.00 & 670.00 & 704.00 \\
\hline $\mathrm{Sb}$ & - & - & 12.60 & 10.90 & 11.80 & 4.43 & 3.60 & 7.30 & 11.00 & 4.20 & 6.20 & 16.40 & 11.60 & 7.90 \\
\hline $\mathrm{La}$ & - & - & 282.00 & 281.00 & 293.00 & 126.80 & 142.00 & 174.00 & - & 167.00 & 175.00 & 245.00 & 220.00 & 151.00 \\
\hline $\mathrm{Ce}$ & - & - & - & - & - & - & - & 51.00 & 50.00 & 31.50 & - & 66.00 & 53.00 & - \\
\hline $\mathrm{Nd}$ & - & - & 222.00 & 238.00 & 236.00 & 109.80 & 119.00 & 136.00 & 100.00 & 113.00 & 133.00 & 174.00 & 140.00 & 119.00 \\
\hline $\mathrm{Sm}$ & - & - & 40.00 & 40.20 & 41.80 & 17.70 & 21.00 & 27.00 & - & 19.30 & 24.10 & 34.00 & 32.00 & 19.90 \\
\hline $\mathrm{Eu}$ & - & - & 11.20 & 10.79 & 11.30 & 5.08 & 6.08 & 7.20 & 8.00 & 6.10 & 7.10 & 9.50 & 8.50 & 5.78 \\
\hline $\mathrm{Tb}$ & - & - & 5.90 & 5.93 & 6.30 & 2.61 & 2.77 & 4.90 & 5.00 & 3.90 & 3.42 & 7.30 & 5.80 & 2.70 \\
\hline $\mathrm{Yb}$ & - & - & 34.00 & 30.20 & 32.00 & 12.20 & 12.60 & 24.00 & 31.00 & 22.00 & 15.50 & 32.00 & 28.00 & 11.60 \\
\hline $\mathrm{Lu}$ & - & - & 7.50 & 6.49 & 6.70 & 2.39 & 2.56 & 3.30 & 4.00 & 2.85 & 3.00 & 4.70 & 3.90 & 2.32 \\
\hline $\mathrm{Hf}$ & - & - & 4.95 & 4.34 & 4.49 & - & - & 2.30 & - & - & - & - & 2.50 & 2.01 \\
\hline $\begin{array}{l}\text { Th } \\
\text { Salt, } \mathrm{CaCO}_{3} \text { corrections }\end{array}$ & - & - & - & - & - & - & - & 2.00 & - & - & - & 1.98 & 1.70 & - \\
\hline Correction factor & 1.53 & 1.28 & 1.23 & 1.21 & 1.35 & 2.78 & 4.92 & 6.17 & 24.08 & 19.40 & 12.42 & 25,04 & 11.80 & 4.75 \\
\hline $\mathrm{Ca}^{\mathrm{a}}(\%)$ & 9.31 & 3.32 & 2.70 & 2.51 & 6.39 & 23.42 & 30.32 & 32.60 & 37.80 & 37.39 & 36.15 & 37.74 & 36.10 & 30.85 \\
\hline $\mathrm{CaCO}_{3}(\%)$ & 21.70 & 6.43 & 4.88 & 4.39 & 14.29 & 57.66 & 75.24 & 80.92 & 94.27 & 93.24 & 90.09 & 94.12 & 90.02 & 76.60 \\
\hline Water $(\%)$ & 78.71 & 81.49 & 79.40 & 78.92 & 76.61 & 64.63 & 55.86 & 45.05 & 31.04 & 31.45 & 34.59 & 34.97 & 30.16 & 39.98 \\
\hline Salt (\%) & 12.94 & 15.41 & 13.49 & 13.10 & 11.46 & 6.40 & 4.43 & 2.87 & 1.58 & 1.61 & 1.85 & 1.88 & 1.51 & 2.33 \\
\hline
\end{tabular}

${ }^{\mathrm{a}}$ Uncorrected. 
TABLE 3 - Continued

\begin{tabular}{|c|c|c|c|c|c|c|c|c|c|c|c|c|c|}
\hline & $319-15$ & $319-16$ & $319-17$ & 319-18 & 319-19 & $320-1$ & $320-2$ & $321-1$ & $321-2$ & $321-3$ & $321-4$ & $321-5$ & $321-6$ \\
\hline Depth in core $(\mathrm{m})$ & 87.87 & 97.31 & 101.58 & 102.92 & 106.89 & 149.91 & 152.40 & 68.31 & 76.01 & 89.31 & 116.84 & 117.85 & 119.76 \\
\hline \multicolumn{14}{|l|}{ Major elements (\%) } \\
\hline $\mathrm{Fe}(\mathrm{AASC})$ & 18.80 & 29.00 & 29.00 & 28.00 & 22.00 & 17.10 & 23.60 & 15.40 & 26.90 & 24.00 & 27.00 & 27.94 & 14.20 \\
\hline $\mathrm{Fe}$ (INAA) & 19.60 & 29.00 & 31.10 & 29.00 & 19.00 & 18.70 & 24.60 & 15.50 & 26.60 & 26.00 & 27.00 & 29.60 & 14.90 \\
\hline $\mathrm{Mn}$ & 5.40 & 8.90 & 8.70 & 8.50 & 5.10 & 7.90 & 10.80 & 3.37 & 5.70 & 5.80 & 13.80 & 14.76 & 3.70 \\
\hline $\mathrm{Si}$ & 5.00 & 5.50 & 5.84 & 5.40 & 9.00 & 8.90 & 11.40 & 19.00 & 12.60 & 15.00 & 7.60 & 4.99 & 23.80 \\
\hline $\mathrm{Al}$ & 0.80 & 1.00 & 1.03 & 0.89 & 1.30 & 0.88 & 1.12 & 6.73 & 4.37 & 4.70 & 2.10 & 1.33 & 4.00 \\
\hline $\mathrm{Ba}(\mathrm{AASC})$ & 0.54 & 0.52 & 0.54 & 0.74 & 0.74 & 0.50 & 0.61 & 0.19 & 0.11 & 0.57 & 0.35 & 0.35 & 0.06 \\
\hline $\mathrm{Ba}$ (INAA) & 0.50 & 0.45 & 0.42 & 0.64 & 0.61 & 0.44 & 0.62 & 0.15 & 0.10 & 0.54 & 0.34 & 0.32 & 0.07 \\
\hline \multicolumn{14}{|c|}{ Trace elements (ppm) } \\
\hline $\mathrm{Sc}$ & 7.60 & 8.70 & 8.20 & 8.60 & 7.10 & 5.20 & 6.10 & 24.10 & 17.10 & 23.00 & 11.60 & 7.76 & 26.90 \\
\hline $\mathrm{Cr}$ & 12.90 & 17.10 & 33.00 & 28.00 & 22.00 & - & 23.00 & 40.00 & 31.00 & - & 27.00 & 19.20 & 17.30 \\
\hline $\mathrm{Co}$ & 94.00 & 127.00 & 133.00 & 122.00 & 74.00 & 62.00 & 84.00 & 224.00 & 185.00 & 230.00 & 123.00 & 101.20 & 54.00 \\
\hline $\mathrm{Ni}$ & 480.00 & 800.00 & 690.00 & 700.00 & 490.00 & 580.00 & 650.00 & 530.00 & 690.00 & 700.00 & 1430.00 & 1390.00 & 480.00 \\
\hline $\mathrm{Cu}$ & 1070.00 & 1490.00 & 1410.00 & 1400.00 & 1300.00 & 1030.00 & 1290.00 & 927.00 & 1190.00 & 1500.00 & 1420.00 & 1439.00 & 500.00 \\
\hline $\mathrm{Zn}$ & 470.00 & 670.00 & 630.00 & 570.00 & 510.00 & 550.00 & 730.00 & 418.00 & 650.00 & 730.00 & 870.00 & 885.40 & 390.00 \\
\hline $\mathrm{Sb}$ & 5.60 & 7.70 & 8.20 & 7.20 & 5.20 & 2.56 & 3.50 & 9.10 & 13.90 & 7.50 & 8.80 & 7.70 & 1.16 \\
\hline $\mathrm{La}$ & 112.00 & 137.00 & 137.00 & 150.00 & 84.00 & 76.00 & 85.00 & 208.00 & 206.00 & 220.00 & 180.00 & 168.00 & 33.00 \\
\hline $\mathrm{Ce}$ & 27.00 & 34.00 & - & - & - & - & 27.00 & 116.00 & - & 110.00 & 48.00 & - & 17.40 \\
\hline $\mathrm{Nd}$ & 83.00 & 85.00 & 113.00 & 122.00 & 76.00 & 54.00 & 86.00 & 161.00 & 132.00 & 180.00 & 141.00 & 140.10 & 30.00 \\
\hline $\mathrm{Sm}$ & 17.20 & 18.20 & 18.40 & 20.00 & 12.00 & 10.60 & 13.40 & 35.90 & 33.70 & 40.00 & 29.00 & 22.70 & 7.20 \\
\hline $\mathrm{Eu}$ & 4.50 & 5.20 & 5.11 & 5.20 & 3.40 & 3.24 & 3.80 & 9.50 & 8.30 & 12.00 & 7.70 & 6.52 & 2.03 \\
\hline $\mathrm{Tb}$ & 2.90 & 3.50 & 2.56 & 2.70 & 1.50 & 1.41 & 2.31 & 6.30 & 5.20 & 6.60 & 4.90 & 2.78 & 1.37 \\
\hline $\mathrm{Yb}$ & 14.00 & 17.00 & 11.00 & 12.00 & 7.40 & 6.20 & 12.20 & 27.00 & 24.00 & 31.00 & 28.00 & 11.70 & 5.60 \\
\hline $\mathrm{Lu}$ & 2.10 & 2.40 & 2.23 & 2.40 & 1.50 & 1.31 & 1.75 & 3.89 & 3.20 & 4.30 & 3.10 & 2.25 & 0.77 \\
\hline Hf & 1.15 & 1.75 & - & - & - & - & - & 4.99 & 2.87 & - & 2.10 & 0.81 & 2.93 \\
\hline Th & 0.62 & 1.11 & - & - & - & - & - & 7.90 & 4.10 & 4.40 & 1.83 & - & - \\
\hline \multicolumn{14}{|c|}{ Salt, $\mathrm{CaCO}_{3}$ corrections } \\
\hline Correction factor & 8.72 & 6.26 & 5.99 & 9.06 & 8.64 & 8.30 & 10.12 & 2.44 & 2.24 & 29.55 & 7.38 & 4.44 & 3.62 \\
\hline $\mathrm{Ca}^{\mathrm{a}}(\%)$ & 35.00 & 33.00 & 32.90 & 35.00 & 34.80 & 34.59 & 35.40 & 22.60 & 21.30 & 38.10 & 33.80 & 30.34 & 28.10 \\
\hline $\mathrm{CaCO}_{3}(\%)$ & 87.16 & 82.18 & 81.76 & 87.06 & 86.56 & 86.12 & 88.28 & 55.54 & 52.24 & 94.95 & 84.07 & 75.31 & 69.63 \\
\hline Water $(\%)$ & 28.07 & 34.54 & 30.59 & 35.21 & 34.71 & 34.34 & 34.44 & 49.76 & 46.91 & 32.27 & 40.45 & 38.36 & 44.12 \\
\hline Salt (\%) & 1.37 & 1.85 & 1.54 & 1.90 & 1.86 & 1.83 & 1.84 & 3.47 & 3.09 & 1.67 & 2.38 & 2.18 & 2.76 \\
\hline
\end{tabular}




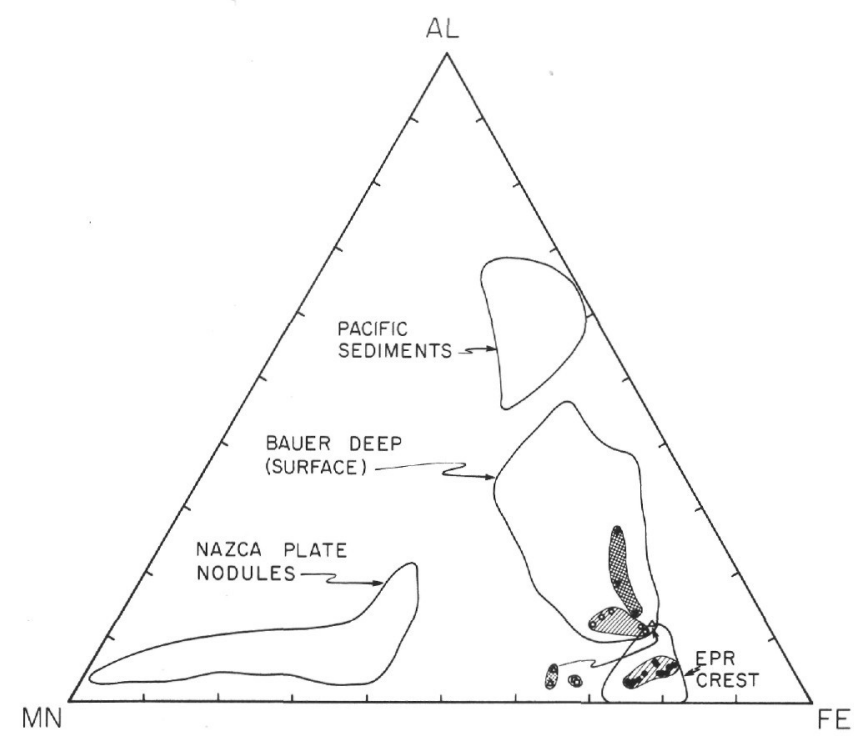

Figure 2. Al-Fe-Mn plot of 319, 320B, and 321 data.

hydrothermal processes accompanying mid-ocean ridge volcanism. Several of the elements, including $\mathrm{Si}, \mathrm{Al}, \mathrm{Ni}$, $\mathrm{Co}, \mathrm{Ba}, \mathrm{Sb}, \mathrm{Sc}$, and the rare earth elements (REE), are dramatically enriched in the upper 20 meters of the core (Figures 5, 6, and 7). Since these surficial sediments were deposited after the site moved well away from the Galapagos Rise and into the Bauer Deep, it is tempting to suggest that they have a seawater origin rather than a hydrothermal origin. This possibility is supported by the REE abundance pattern which is very similar to the seawater pattern (Figure 8). As will be discussed in more detail below, there are other possible interpretations of these data. The point we wish to make here is that the contrasting elemental abundance patterns are not unique to this core. They have been observed in surface samples recovered from the EPR and the Bauer Deep (Dymond et al., 1973; Bischoff and Sayles, 1972) and must be accounted for in any model for the origin of Nazca plate metalliferous sediments.

Calcium carbonate content varies from approximately $80 \%$ near the bottom of Site 319 to a maximum of approximately $90 \%$ at 50 meters and then decreases to a few percent in the upper 10 meters. These $\mathrm{CaCO}_{3}$ variations mark the movement of Site 319 from its position on the crest of the Galapagos Rise to its present location below the calcite compensation depth (CCD). The maximum $\mathrm{CaCO}_{3}$ content at 50 meters can be the result of a rapid decrease in the accumulation of the metalliferous components away from the spreading center (Table 2 ), and a relatively constant accumulation of carbonate at depths shallower than the lysocline.

\section{Metal Accumulation Rates}

If we consider metal accumulation rates of Site 319, a rather different picture than that exhibited by concentration data emerges (Table 2 and Figure 9). Accumulation rates of $\mathrm{Mn}, \mathrm{Fe}$, and $\mathrm{Ni}$ are high in sediments less than a million years younger than basement ; an expected result for sediments formed by hydrothermal processes accompanying mid-ocean ridge volcanism.
Aluminum and silicon accumulation rates, however, also reach a maximum near basement in spite of the fact that both elements have maximum concentrations in the youngest sediments at this site. This is possible because sedimentation rates increase by a factor of 30 from surface to near basement in this core. Any elements which do not show approximately this same concentration enrichment from bottom to top will have higher accumulation rates in the lower part of the core. The compositional differences between near-surface and nearbasement sediments at this site are possible because the accumulation rates of $\mathrm{Mn}$ and $\mathrm{Fe}$ decrease by a factor of 50 from basement to near-surface, while $\mathrm{Si}, \mathrm{Al}, \mathrm{Ni}$, and other minor element accumulation rates decrease by a factor of approximately 10 or less.

Most studies of marine sediments have concluded that $\mathrm{Al}$ and nonbiogenous Si concentrations are primarily controlled by accumulation of detrital phases. This concept is undoubtedly true in many regions of the ocean; however, we suggest that on the Nazca plate these elements may be dominated by hydrothermal sources. An alternative hypothesis is that the high accumulation rates of $\mathrm{Si}$ and $\mathrm{Al}$ in the basal sediments result from detrital, volcanogenic phases which are easily weathered from the numerous exposed outcrops on mid-ocean ridges. If detrital phases were to account for all the aluminum in the Hole 319 sediments, there would have to be approximately $10 \%$ volcanogenic detritus in the basal sediments and 30\%-50\% detrital phases in the near-surface sediments. Detrital phases are extremely rare in these sediments. An occasional sample has volcanic glass or rock fragments; however, both X-ray diffraction and microscopic examination of these sediments suggest that this component comprises generally less than $1 \%$ of the sediment mass (Dasch et al., 1971).

Si-Al ratios also indicate a nonbasaltic source for these elements in the sediment. With the exception of Samples 319-6 and 319-7, the Si-Al ratios do not deviate greatly from a value of six (Figure 10). If detrital phases

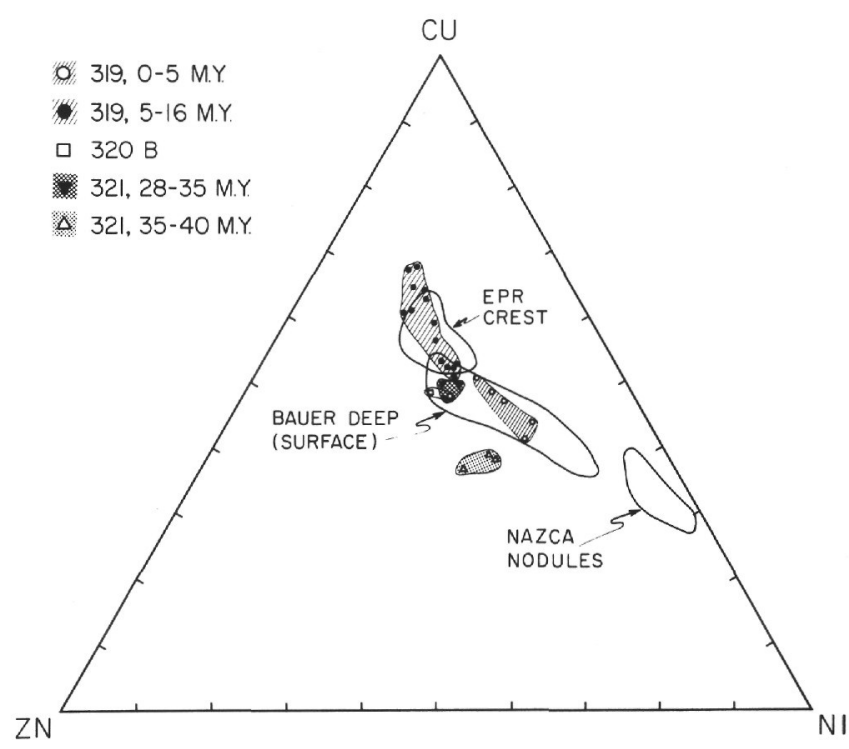

Figure 3. Cu-Ni-Zn plot of 319, 320B, and 321 data. 


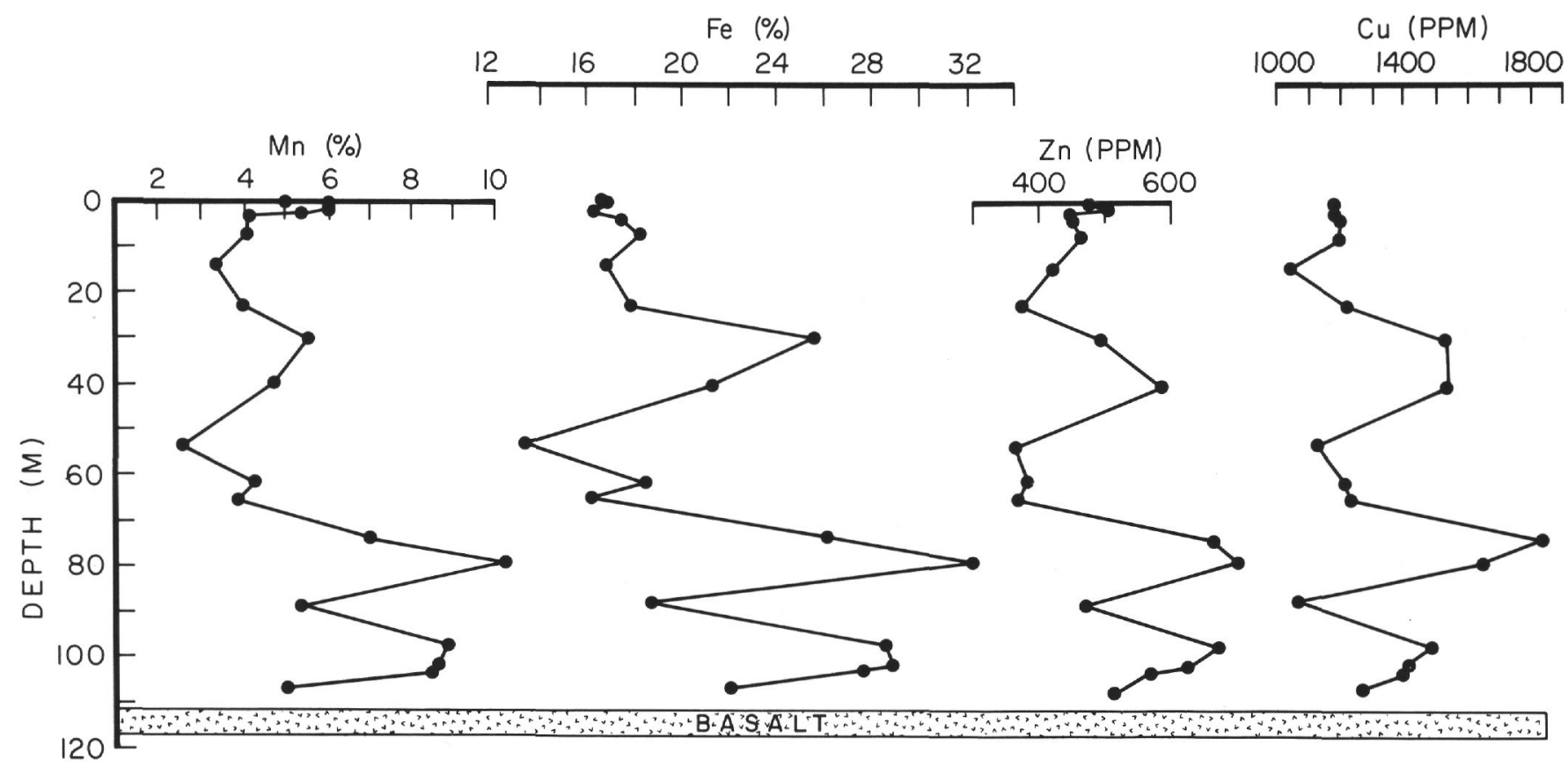

Figure 4. Carbonate and salt corrected sediment compositions of Site 319 versus depth from sediment surface.

were accounting for the $\mathrm{Si}$ and $\mathrm{Al}$ in both near-bottom and near-surface sediments, generally lower and more variable $\mathrm{Si} / \mathrm{Al}$ values would be expected. Volcanogenic detritus with $\mathrm{Si} / \mathrm{Al}$ equal to approximately three might be expected in basal sediments; however, near-surface sediments, as a result of extremely slow sedimentation rates, might contain some continental detritus with higher $\mathrm{Si} / \mathrm{Al}$ values. We shall discuss the significance of the high $\mathrm{Si}$ and $\mathrm{Si} / \mathrm{Al}$ values in Sample 319-6 and 319-7 below.

Hydrothermal addition of $\mathrm{Si}$ to the sediments is a reasonable process. The solubility of $\mathrm{Si}$ in water increases rapidly with increasing temperature (Morey et al., 1962), and circulating seawater through cooling basalt would undoubtedly leach silica (Corliss, 1971). Relatively high concentrations of silica are observed in seawater hydrothermal systems (Tomasson and Kristmannsdottir, 1972; Brewer and Spencer, 1969).

The addition of aluminum by hydrothermal processes is more conjectural. Aluminum is rarely measured in hydrothermal solutions and is known to have very low solubility in aqueous solutions (Garrels and Christ, 1965). A possible mechanism for releasing aluminum into a seawater hydrothermal system is the albitization of feldspars. This reaction is important in greenschist metamorphism, a common metamorphic facies in the oceanic crust (Melson et al., 1968).

Another interesting relationship in this report is that of $\mathrm{Fe}$ and $\mathrm{Si}$. From the metal accumulation rate data (Table 2), it is apparent that these elements are very closely correlated in the upper part of Site 319 sediments. In the upper 23 meters of sediment (approximately the last $10 \mathrm{~m} . \mathrm{y}$. of deposition), the $\mathrm{Si}$ and $\mathrm{Fe}$ accumulation rates are equal. Deeper in the core, however, Fe accumulates more rapidly than $\mathrm{Si}$ and near basement is approximately five times higher in concen- tration. It is probable that both $\mathrm{Fe}$ and $\mathrm{Si}$ are fixed primarily in the form of an Fe-smectite in the upper 20 meters of the core. Eklund (1973) found smectite to be the most important Fe-bearing phase in the Bauer Deep and from microprobe analyses of individual smectite grains determined an $\mathrm{Fe} / \mathrm{Si}$ value of $0.91 \pm 0.20$ for this phase. Deeper in the core some of the Si may be in the form of smectite as this phase is known to be present in surface samples from the EPR Crest (Kendrick, 1973). Presumably, in the basal sediments the excess iron over that required to form Fe-smectites must largely be in the form of amorphous iron hydroxides and oxides.

\section{Models of Sedimentation}

Several hypotheses can be proposed to account for the vertical change in composition of the metalliferous sediments at Site 319 . If the change in composition

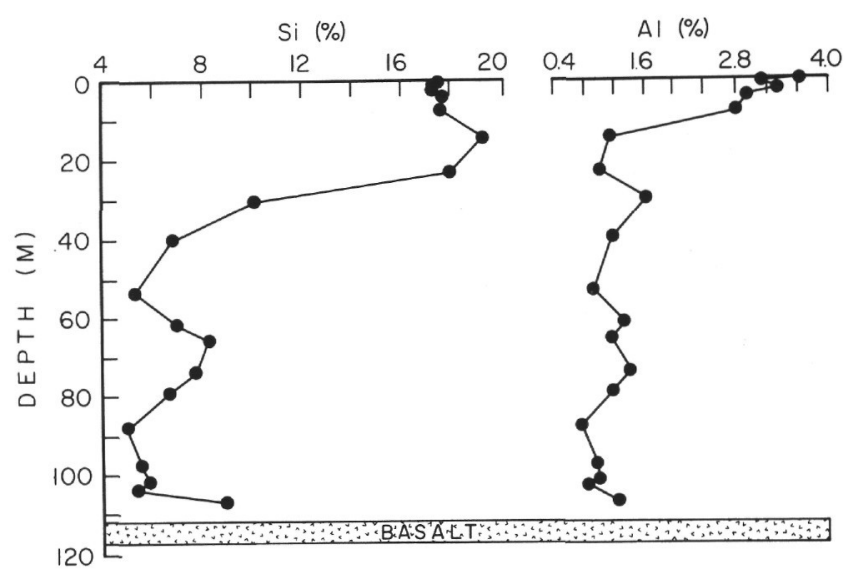

Figure 5. Carbonate and salt corrected sediment compositions of Site 319 versus depth from sediment surface. 


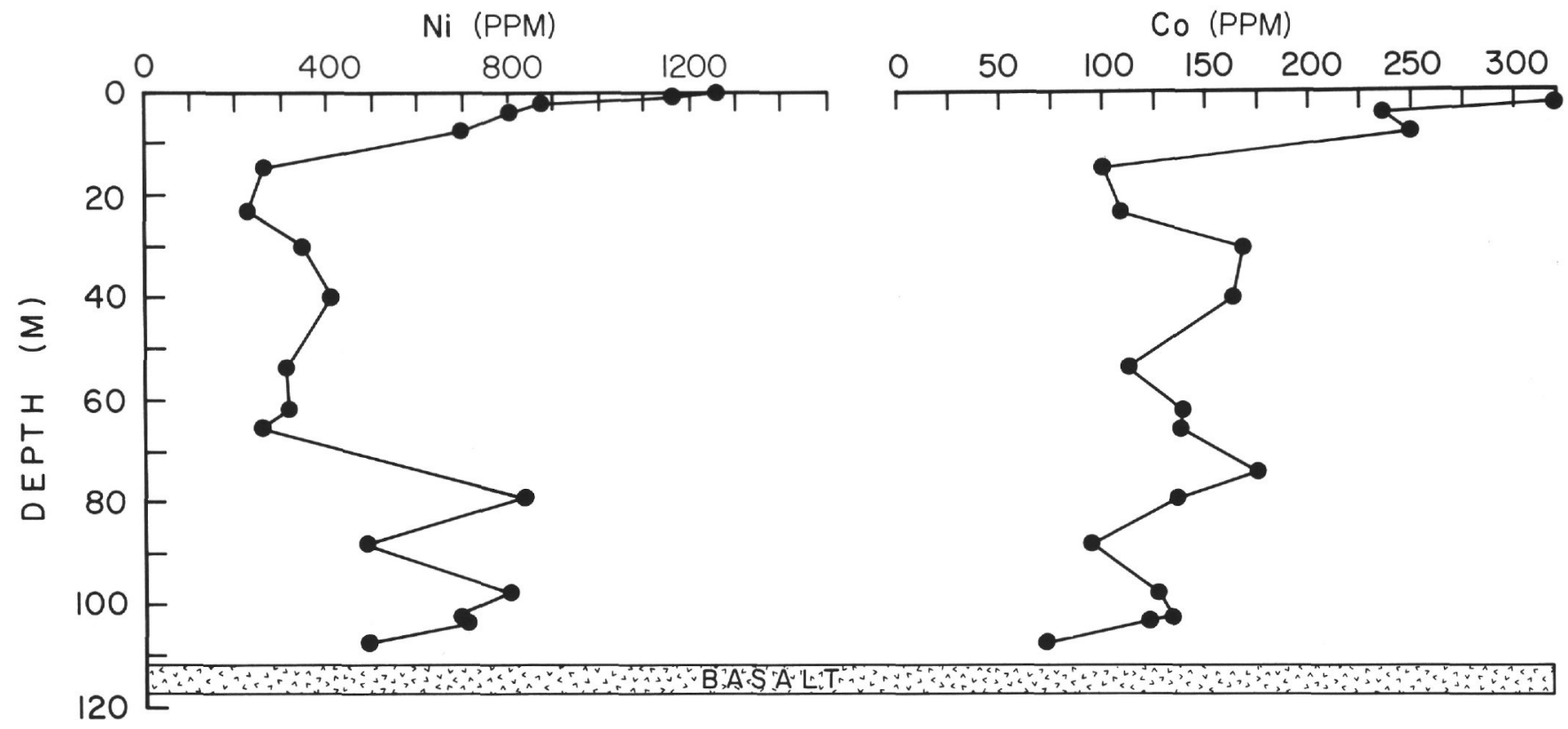

Figure 6. Carbonate and salt corrected sediment compositions of Site 319 versus depth from sediment surface.

results from an increase in the distance of the site from the hydrothermal source, the composition may reflect (1) adsorption of elements from seawater during transport of solid phases or addition of new solid phases (for example, Fe-Mn micronodules) by precipitation from seawater, or (2) fractionation of elements due to different rates of precipitation so that, for example, iron may precipitate rapidly and be concentrated in sediments near the source, while manganese and silica precipitate more slowly and thus further from the source. The change in composition may also result from initiation of volcanic activity and associated hydrothermal activity which produce hydrothermal products of a different composition.

If the first of these mechanisms is operating, the surface Bauer Deep sediments will consist of authigenic phases precipitated directly from seawater or primary hydrothermal phases transported from the EPR that have adsorbed elements from seawater or a mixture of these two. There is support for this model in some of the chemical trends in the data. The sediments become relatively more enriched through time in the trace metals, $\mathrm{Ni}$ and $\mathrm{Co}$, relative to iron and manganese. Ferromanganese nodules, which may represent the authigenic precipitation, typically have higher $\mathrm{Ni}$ and Co contents than crestal EPR sediments. Also, Figure 3 suggests that the surface Bauer Deep sediments lie on a compositional tieline between metalliferous sediments from the EPR crest and Nazca plate nodules.

The metal accumulation rate data (Table 2 and Figure 11) are compatible with this model as well. Data on manganese accumulation rates in nodules and sediments (Bender et al., 1970) suggest that hydrogenous manganese accumultaion in the Pacific is approximately $1 \mathrm{mg} / \mathrm{cm}^{2} / 1000 \mathrm{yr}$. The low rates of manganese and the minor transition metal accumulation in the Bauer Deep suggest that authigenic precipitation could provide a significant fraction of the total accumulation of metals.
The second hypothesis, that fractionation of elements may occur during the precipitation process, is based on the concept that different metals precipitate at different rates from hydrothermal solutions entering seawater. Boström (1970) has favored this as an explanation for the decrease in $\mathrm{Fe} / \mathrm{Mn}$ and $\mathrm{Fe} / \mathrm{Co}$ values away from the EPR. He suggests, on the basis of stability relationships of $\mathrm{Fe}, \mathrm{Mn}, \mathrm{Ni}$, and Co (Pourbaix et al., 1963), that the order of precipitation is $\mathrm{Fe}, \mathrm{Mn}, \mathrm{Ni}$, and $\mathrm{Co}$ in oxygenated seawater. We might also add $\mathrm{Si}$ as a relatively mobile element which, because of its relatively high solubility, may enter the dissolved silica load of seawater. Evidence that fractionation of elements takes place in marine hydrothermal systems can be inferred by the dramatic fractionation of $\mathrm{Fe}$ and $\mathrm{Mn}$ observed in a few deep-sea deposits thought to be of hydrothermal origin. Bonatti and Joensuu (1966) and Piper et al. (in press) have reported on extremely Fe-rich deposits which have uranium isotopic compositions (Veeh and Boström, 1971) and rare earth abundances suggestive of a hydrothermal origin. The deposits described in these studies have very low abundances of the trace transition elements and in one case an anomalously enriched manganese deposit is associated with the iron deposits. Another example of $\mathrm{Fe}$ and $\mathrm{Mn}$ fractionation may be the highly manganese enriched crusts recovered from the Mid-Atlantic Ridge (Scott et al., 1974). A hydrothermal origin for these crusts is indicated by the U-Th disequilibrium and their unusual composition compared to other Fe-Mn nodules. These rather dramatic fractionation effects, however, are rather rare and the $\mathrm{Fe} / \mathrm{Mn}$ ratio is relatively constant for all of the Nazca plate metalliferous sediments $(\mathrm{Fe} / \mathrm{Mn}=3.5 \pm 1.8)$. Furthermore, it may be simplistic to think that formation of oxides and hydroxides of the trace transition metals $(\mathrm{Cu}$, $\mathrm{Ni}, \mathrm{Zn}$, and $\mathrm{Co}$ ) is the cause of their removal to the sediments. These elements are more likely removed by coprecipitation and adsorption with the more major 


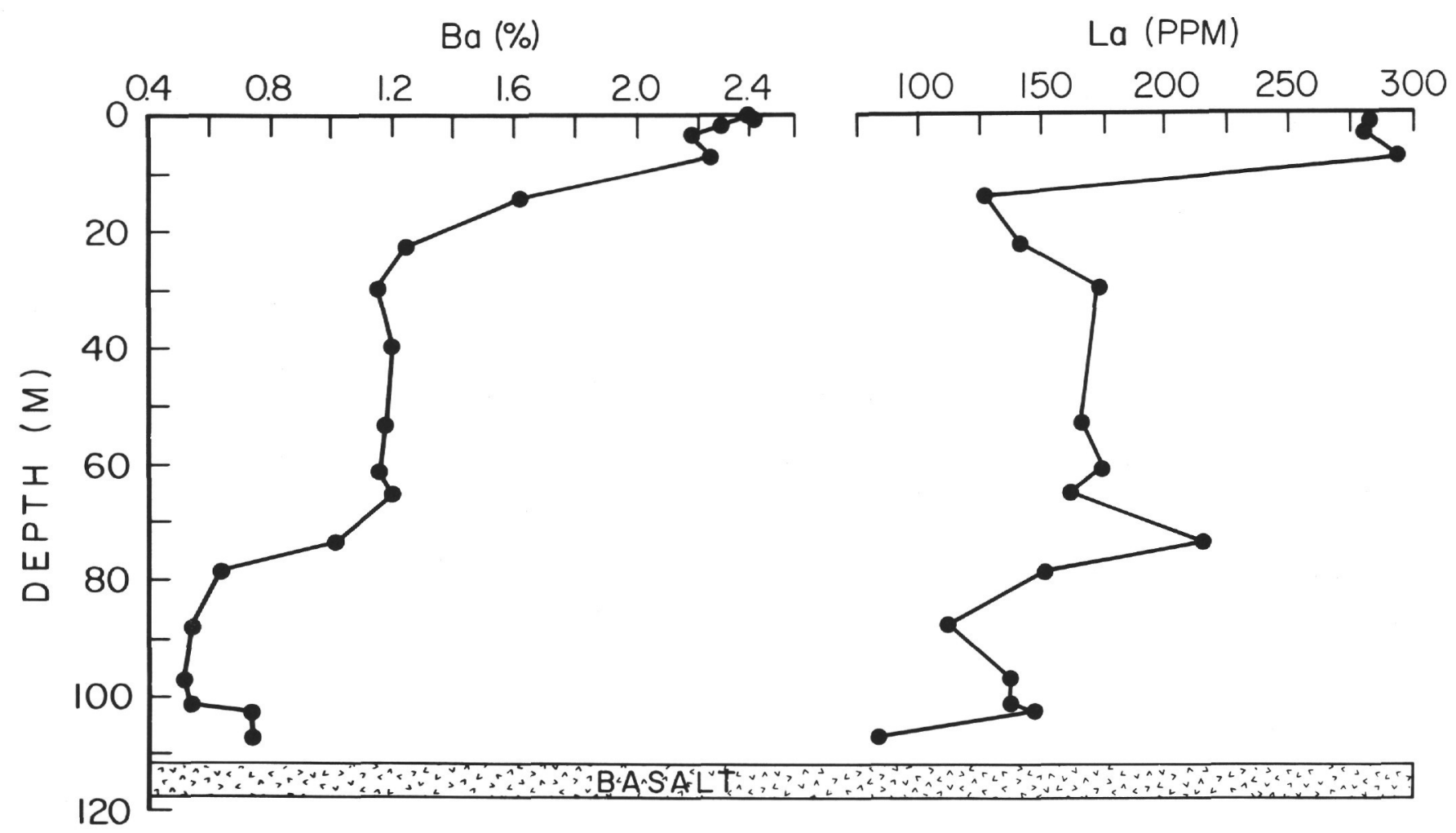

Figure 7. Carbonate and salt corrected sediment compositions of Site 319 versus depth from sediment surface.

phases. Thus, differences in the stability relationships of the different transition metals are not the likely explanation for the compositional differences of near-surface and near-bottom sediments of Site 319. It may be more feasible, however, that a silicate phase (smectite) precipitating from a hydrothermal solution could have a different grain size than the precipitated iron and manganese phases, and would be subject to transport to a greater or lesser degree.

The third hypothesis would account for the differences between the near-surface and near-basement compositions of Site 319 only if a new hydrothermal system and resulting fluids released to seawater had a different chemical composition than the original Galapagos Rise system. Mid-plate volcanism could result from the rearrangement of plate motions which occurred with the jump of spreading from the Galapagos Rise to the EPR. Alternatively, volcanism on the newly formed EPR could be the source of hydrothermal products in the near-surface sediments of this site. Anderson and Halunen (1974) have argued on the basis of a bimodal heat-flow distribution in the Bauer Deep for a local hydrothermal source of Bauer Deep metalliferous sediments. Both possibilities seem somewhat untenable at the present time. Presently there is no evidence of mid-late volcanism in the Bauer Deep region. The ages of basement and the overlying sediments of Site 319 are concordant (Hogan and Dymond, this volume) and suggest the basalts were emplaced on the Galapagos Rise. The bimodal heat-flow distribution itself is questionable, since it is largely indicated by the presence of only 2 or 3 heat-flow measurements in the Bauer Deep with values between 3 and 5 heat-flow units (Anderson and Halunen, 1974). In addition, there is no evidence that the EPR hydrothermal system is producing sediments with a composition similar to near-surface Bauer Deep sediments. Sediments recovered from the crestal EPR strongly resemble the near-basement sediments of Site 319 and are distinctly different than the surface Bauer sediments (Figures 2 and 3).

Although hydrothermal activity from the EPR is not a probable explanation for the dramatic compositional differences of near surface and basal sediments from Site 319 , there is evidence that the formation of the EPR is reflected in subtle ways in the sediments. Site 319 is located approximately $300 \mathrm{~km}$ east of a topographic scarp (Bauer Scarp) which appears to mark the boundary between the more recent crust produced by the EPR and older crust produced by the Galapagos spreading center (Rea, in preparation). Site 319 is nearly $600 \mathrm{~km}$ from the Galapagos spreading center. Thus, at the time the EPR was beginning to form, the nearest source of volcanism and hydrothermally produced products was the EPR. Would this closer new source of volcanism result in a detectable increase in hydrothermal products at this site? Rea (in preparation) estimates that the initiation of spreading at the EPR began approximately $8 \mathrm{~m} . y$. ago. Figure 9 and Table 2 suggest that at 8 m.y., represented by Sample 319-6, the accumulation rate of metals is higher than in samples above or below this depth. Furthermore, in Figure 11 we see that for Site 319 the relatively smooth almost exponential decrease in manganese accumulation rate is perturbed at this age depth of the core. Because Site 319 is $300 \mathrm{~km}$ from the probable location of the incipient 


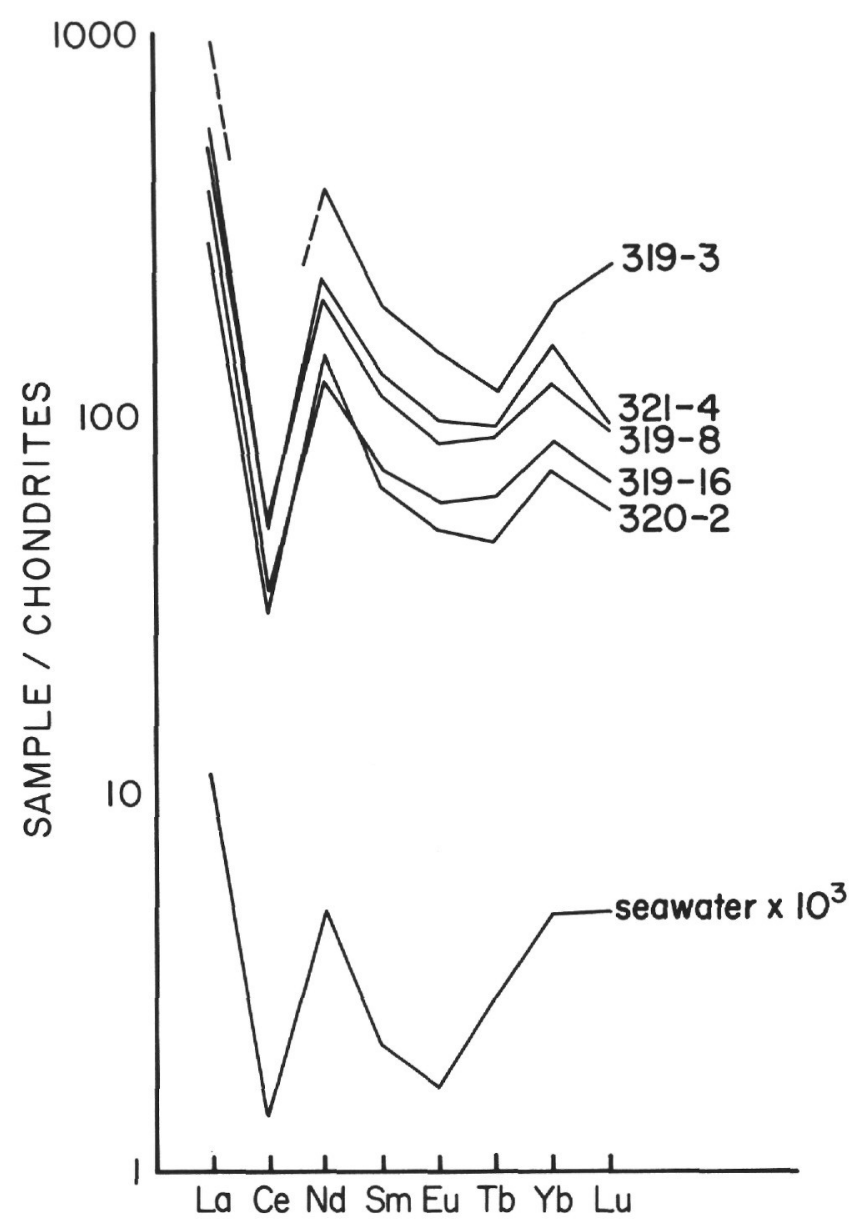

Figure 8. Carbonate and salt corrected rare earth compositions of Leg 34 sediments normalized to the chondritic rare earth abundances of Haskin et al. (1967). The normalized seawater pattern uses data of Hogdahl et al. (1968).

EPR, a large perturbation in the metal accumulation rate with the initiation of spreading would not be expected. This distance (equivalent to 3-4 m.y.) would mean only a 2-3 times increase in rate over the expected rate due to volcanism on the Galapagos Rise (Figure 11).

Due to the scatter in the accumulation rate data through time for Site 319, this interpretation is speculative. There are subtle, chemical variations in Samples 319-6 and 319-7, however, which we further speculate are due to the beginning of hydrothermal activity on the EPR. For example, Fe/Ni values, which are always higher for ridge-crest sedimentation compared to the Bauer Deep (Dymond et al., 1973) reach a maximum in Samples 319-6, 319-7, and 319-8. More dramatic compositional differences are exhibited by the $\mathrm{Si} / \mathrm{Al}$ values for 319-6 and 319-7. As discussed above and exhibited by Figure 9, the $\mathrm{Si} / \mathrm{Al}$ value for Site 319 does not vary greatly except for $319-6(\mathrm{Si} / \mathrm{Al}=16.8)$ and $319-7(\mathrm{Si} / \mathrm{Al}$ $=17.5$ ). These high $\mathrm{Si} / \mathrm{Al}$ might be thought to be the result of a sharp increase in biogenous opal content in this portion of the core. Examination of acetic-acidleached smear slides of these two samples, however,

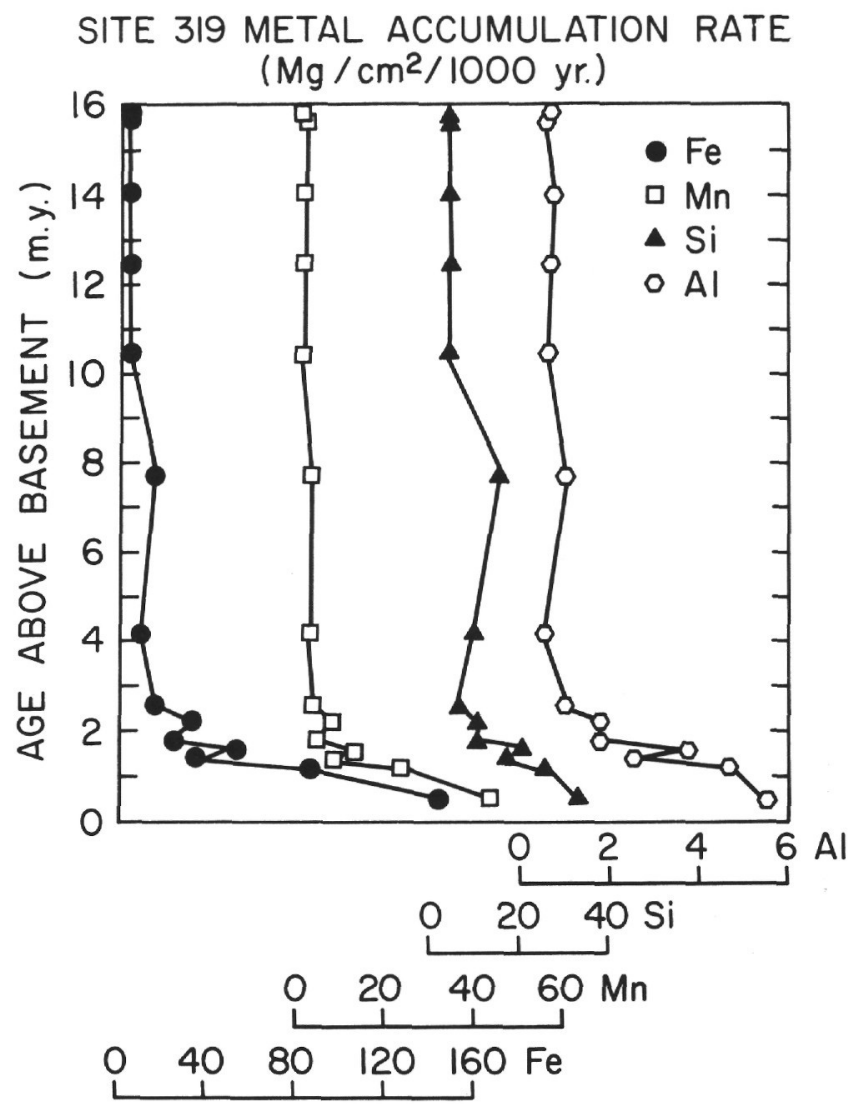

Figure 9. Accumulation rates of $\mathrm{Fe}, \mathrm{Mn}, \mathrm{Si}$, and $\mathrm{Al}$ versus age above basement. Because of the small age difference of the five deepest samples in the core, they have been averaged and are shown as a single point.

reveals no biogenous opal. The noncarbonate sediment fraction of these samples is primarily translucent yellowbrown, equal-dimensional grains, probably a smectite. Thus, the variations in the $\mathrm{Si} / \mathrm{Al}$ ratio in these sediments may result from the existence of different temperature conditions in a newly developing hydrothermal system such as existed when the EPR was beginning. For example, at temperatures $<125^{\circ} \mathrm{C}$ silica in hydrothermal solutions will not be supersaturated with respect to amorphous silica (Morey et al., 1962; Jones and Pytkowicz, 1973) when cooled to seawater temperatures and may enter the dissolved silica budget of seawater. At higher temperatures silica will be supersaturated in cooled hydrothermal solutions and may be initially deposited as amorphous silica which is diagenetically altered to smectites. There may be other explanations for the chemical variations exhibited by these two samples, but it is an intriguing possibility that the timing of the EPR spreading might be discernible in long sediment cores from near the Bauer Scarp.

\section{CONCLUSIONS}

The clear compositional distinctions between the near-basement and near-surface sediments from Site 319 probably result from the superposition of authigenic metal deposition over metal deposition from marine hydrothermal systems. The sharp decrease in the rate of 


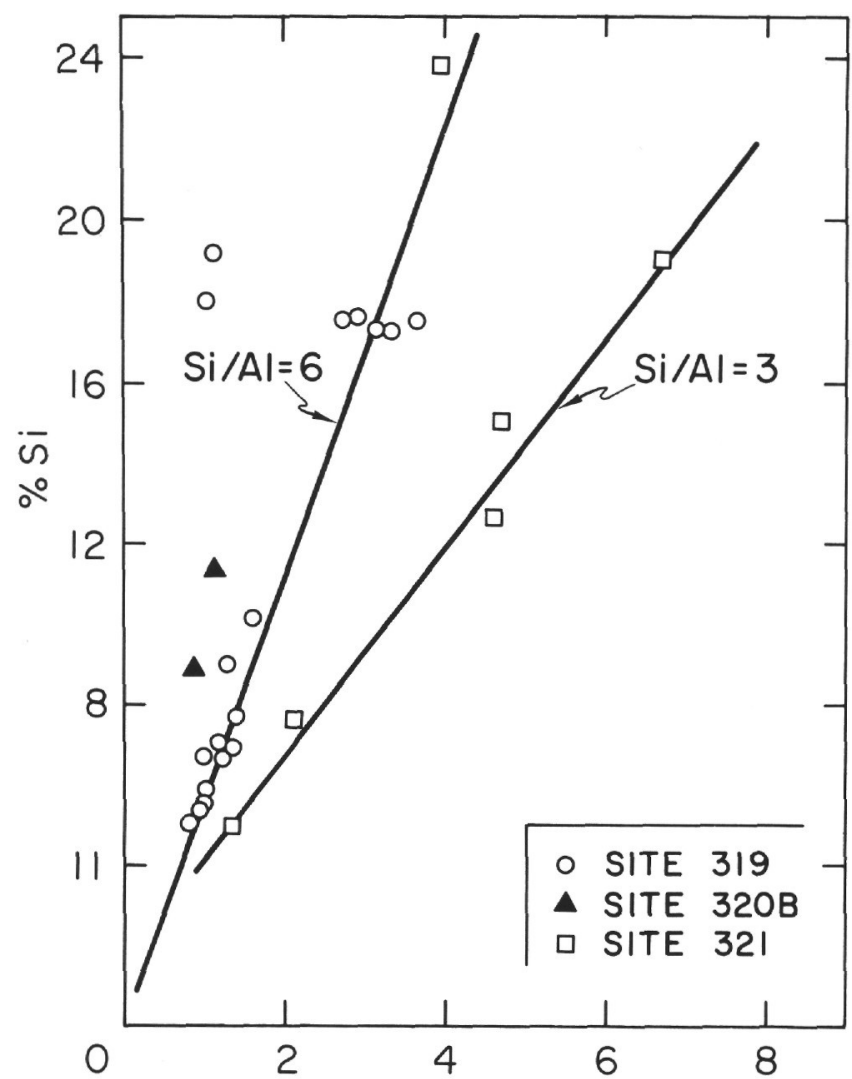

Figure 10. Carbonate and salt corrected silicon versus aluminum concentrations.

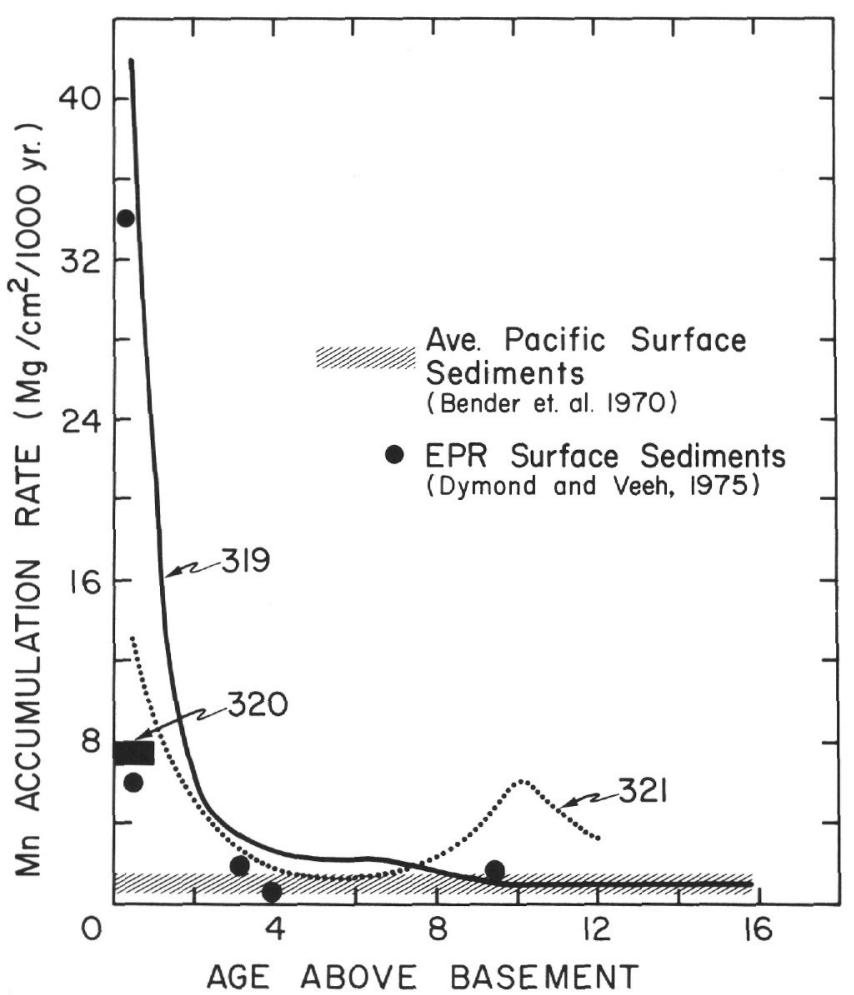

Figure 11. Summary of available Nazca plate manganese accumulation rates plotted against age above basement.

metal deposition through time observed at this site results from movement of the site away from the hydrothermal system inferred to operate on the Galapagos Rise. The relatively constant addition of trace elements by adsorption onto hydrothermally produced phases and authigenic precipitation from seawater becomes an important addition to the sediments deposited far from the spreading center where the sedimentation rate is approximately $0.1 \mathrm{~cm} / 1000 \mathrm{yr}$. Because of the extremely low inputs of continental detritus to this region, the hydrothermal addition of $\mathrm{Fe}$, $\mathrm{Mn}$, and probably $\mathrm{Si}$ and the authigenic addition of $\mathrm{Ni}$, $\mathrm{Co}, \mathrm{Ba}$, and $\mathrm{REE}$ to the sediment dominates the inorganic metal deposition at this site.

There is some evidence in the elemental abundance patterns and the metal accumulation rates for the initiation of sea-floor spreading on the EPR at 8-10 m.y. ago.

\section{Site 320}

The two near-basement samples analyzed from Site 320 show high $\mathrm{Fe}$ and $\mathrm{Mn}$ and low Al values (Figure 2) typical of metalliferous sediments from near spreading centers. The samples are relatively enriched in Mn compared to the other samples analyzed in this study ( $\mathrm{Fe} / \mathrm{Mn} \sim 2$, compared to $\sim 3.5$ for near-bottom Site 319, also see Figure 2). In other respects, such as the relatively high $\mathrm{Fe} / \mathrm{Ni}$ and $\mathrm{Fe} / \mathrm{Co}$ values, low $\mathrm{Ba}$ concentration, these samples strongly resemble the near-basement sediments of Site 319, which suggests a hydrothermal source of metals.

The metal accumulation rates calculated for these samples are approximately 10 times lower than those calculated for near-basement sediments at Site 319 (Table 2, Figure 11). The reasons for this observation are uncertain; however, similar variability in measured metal accumulation rates have been observed for recent sediments deposited on the EPR (Dymond and Veeh, in press, and Figure 11). Sediment ponding, proximity to hydrothermal vents, and variations in spreading rate are some of the factors which could cause variations in the metal accumulation rate. Nonetheless, the $\mathrm{Fe}$ and $\mathrm{Mn}$ accumulation rates for these samples are 5 to 10 times greater than the near-surface sediments from Site 319 and other Pacific pelagic sediments (Table 3 and Bender et al., 1970). This observation and the chemical composition point to a hydrothermal origin for these sediments as well.

\section{Site 321}

The six samples analyzed from Site 321 (Table 3) are from the bottom 60 meters of core in the early Miocene to late Eocene sediments described as nanno-ooze interbedded with zeolite-bearing, iron-rich nanno ooze (Unit 4) in the site survey (this volume). All samples from this part of the core have low $\mathrm{Al}$ and high $\mathrm{Fe}$ concentrations similar to other metalliferous sediments from the Nazca plate (Figure 2). The two youngest samples from the core and the three oldest samples are from the two sections of the core which have a high percentage of ferruginous particles ("RSO" $=10 \%-25 \%$ in Core 9; "RSO" = 15\%-35\% in Core 13, Chapter 5, this volume). The carbonate contents (Table 3 ) indicate a similar trend to the values observed in Site 319 samples, with the maximum $\mathrm{CaCO}_{3}$ content at 35 meters above basement (321-3). These changes presumably 
reflect movement of Site 321 to the east, away from the hydrothermal source of metals on the Galapagos Rise Crest. The reduced carbonate values of the zeolitebearing sediments from Core 9 (321-1 and 321-2) may be an eastern analog to the Bauer Deep. For this site, however, the sediments may be expected to reveal an in creasing continental detrital component with movement of the plate toward the continent.

The strong correlation between $\mathrm{Fe}, \mathrm{Mn}, \mathrm{Zn}$, and $\mathrm{Cu}$ (Figure 12) and the relative enrichment of $\mathrm{Si}, \mathrm{Al}, \mathrm{Co}, \mathrm{Sc}$, $\mathrm{Sb}, \mathrm{Th}$, and REE in the younger sediments (Table 3, Figures 12, 13, 14, and 15) are features of the data shared by both Site 319 and 321 . In contrast, two of the basal sediments from this site (321-4 and 321-5) are enriched in $\mathrm{Mn}$ relative to $\mathrm{Fe}$ compared to other sediments from the Nazca plate (Figure 2). Also 321-4, 321-5, 321-6 do not have the enrichment of $\mathrm{Cu}$ relative to $\mathrm{Ni}$ that other basal sediments and crestal EPR sediments exhibit (Figure 3). The Si/Al values for Site 321 are approximately 3 , except for 321-6, and contrast with the higher values observed in Site 319 samples. Barium and nickel are not greatly enriched in the uppermost two samples analyzed (321-1 and 321-2) as they are in surface Bauer Deep samples (Figures 14 and 15). The significance of these chemical distinctions between the two sites in unclear and may result from such factors as: time variations on the Galapagos Rise hydrothermal system, a greater influence of continental detritus in this area, and east-west variations in productivity and the quantity of metals transported to the sediments by biological vectors.

Some of these factors are evident in the metal accumulation rate data for Site 321 (Table 2, Figure 11). The metals accumulated in the lower 10 meters of the core at rates in excess of those expected by authigenic precipitation; however, at rates approximately five times lower than those determined in Site 319. Also the clear maximum in $\mathrm{Si}$ and $\mathrm{Al}$ accumulation rates, observed in Site 319 basal sediments, is lacking in this core. The metal accumulation rates in the two youngest samples analyzed are more than three times higher than the nearsurface Bauer Deep sediments. This may result from local ponding effects or may indicate that continental detritus is a contributor of $\mathrm{Si}$ and $\mathrm{Al}$ and other metals in the younger samples analyzed. It is possible that sediments from Unit 3, which is lower in $\mathrm{CaCO}_{3}$ and accumulated at very slow rates, is a more proper analog to Bauer Basin sedimentation. However, no sediments from this unit were analyzed.

In summary, the composition of the basal sediments from Site 321 and the rapid rate of metal accumulation suggests that these samples have a hydrothermal origin.

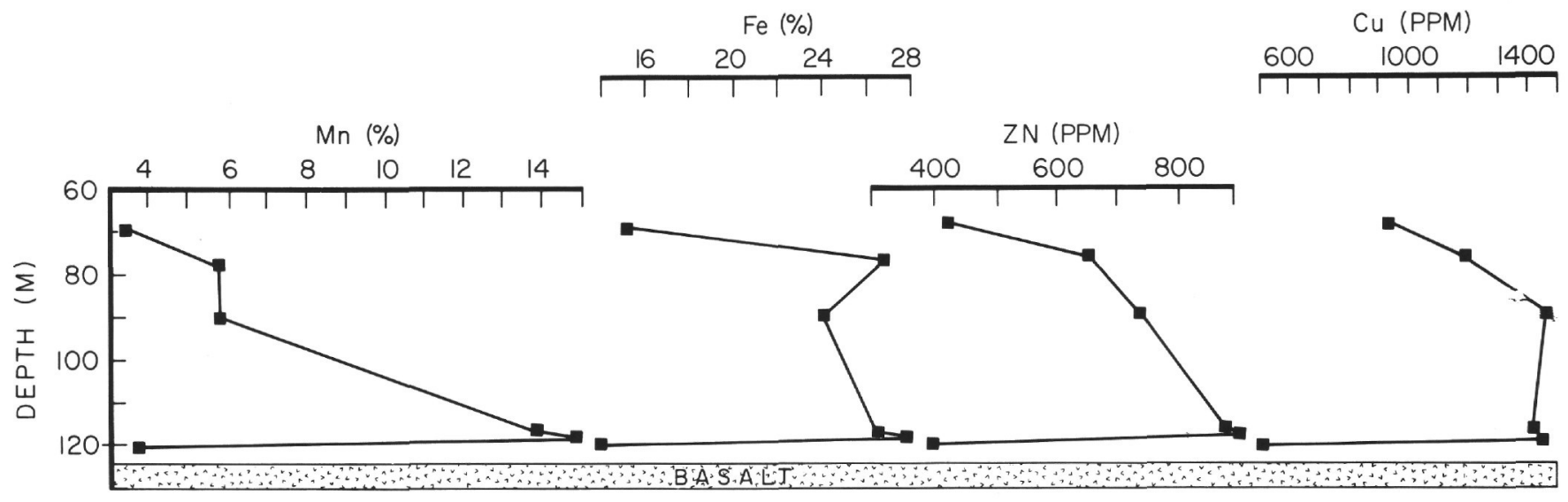

Figure 12. Carbonate and salt corrected sediment composition data for Site 321.

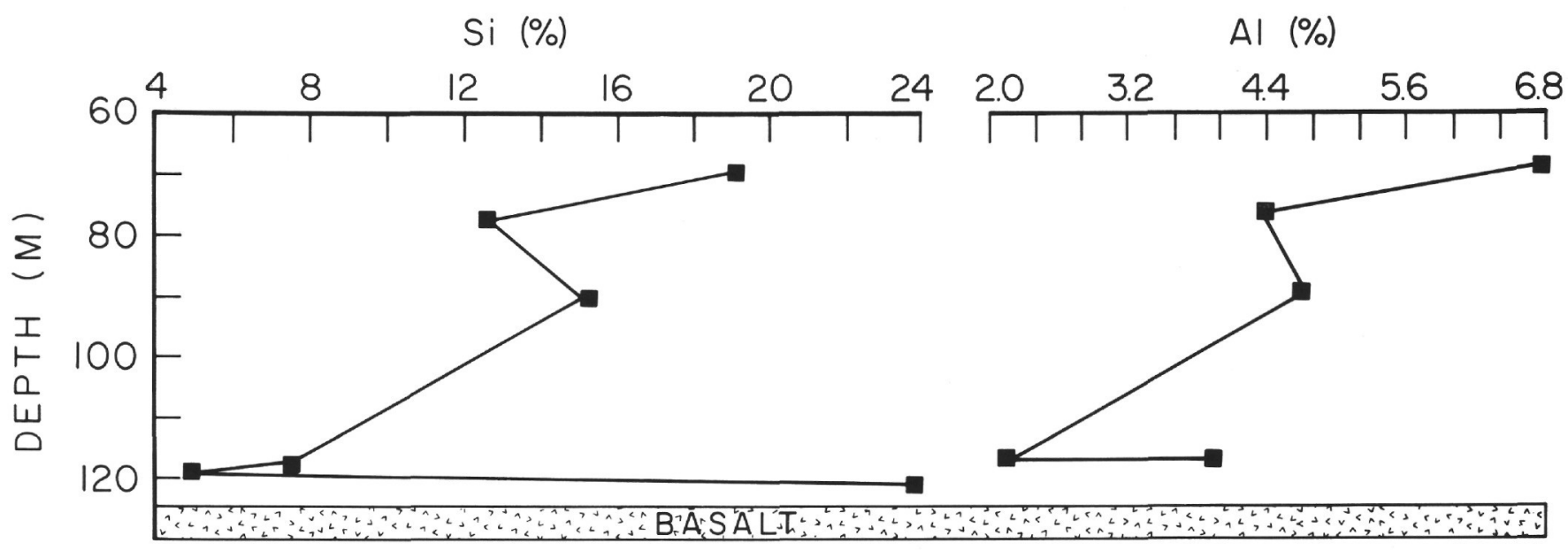

Figure 13. Carbonate and salt corrected sediment composition data for Site 321. 


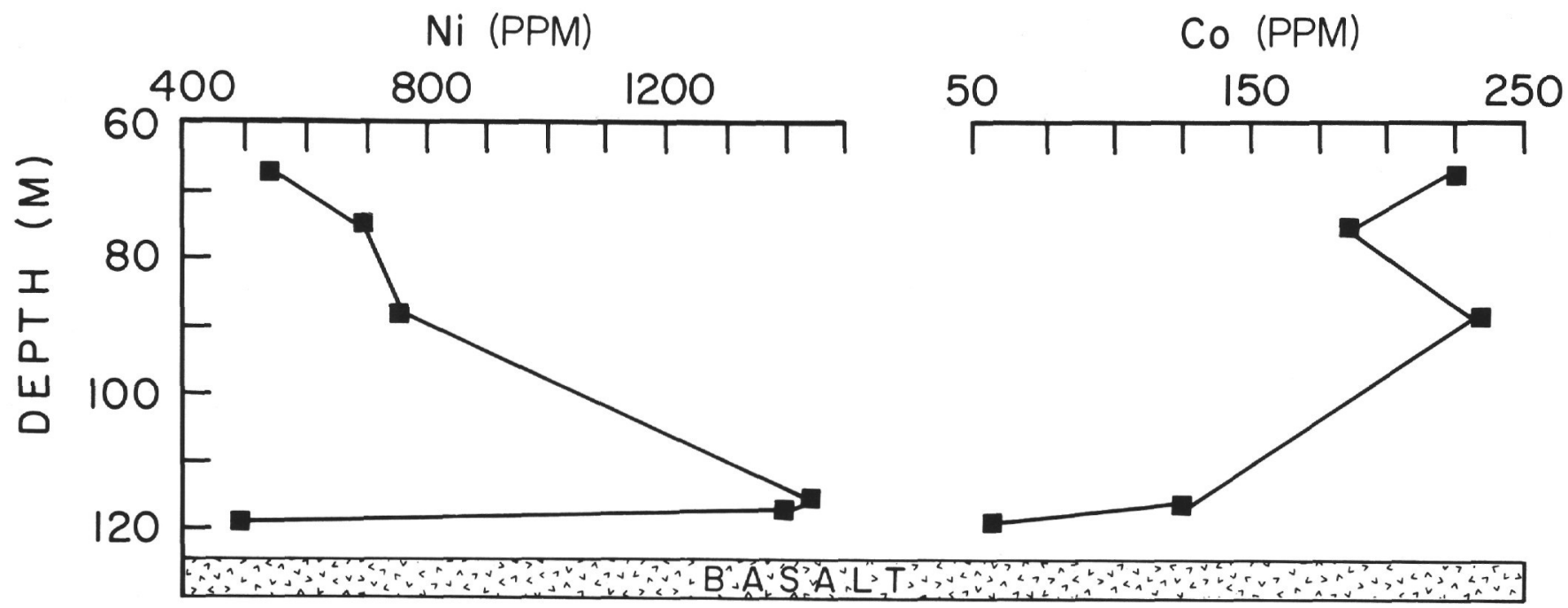

Figure 14. Carbonate and salt corrected sediment composition data for Site 321.

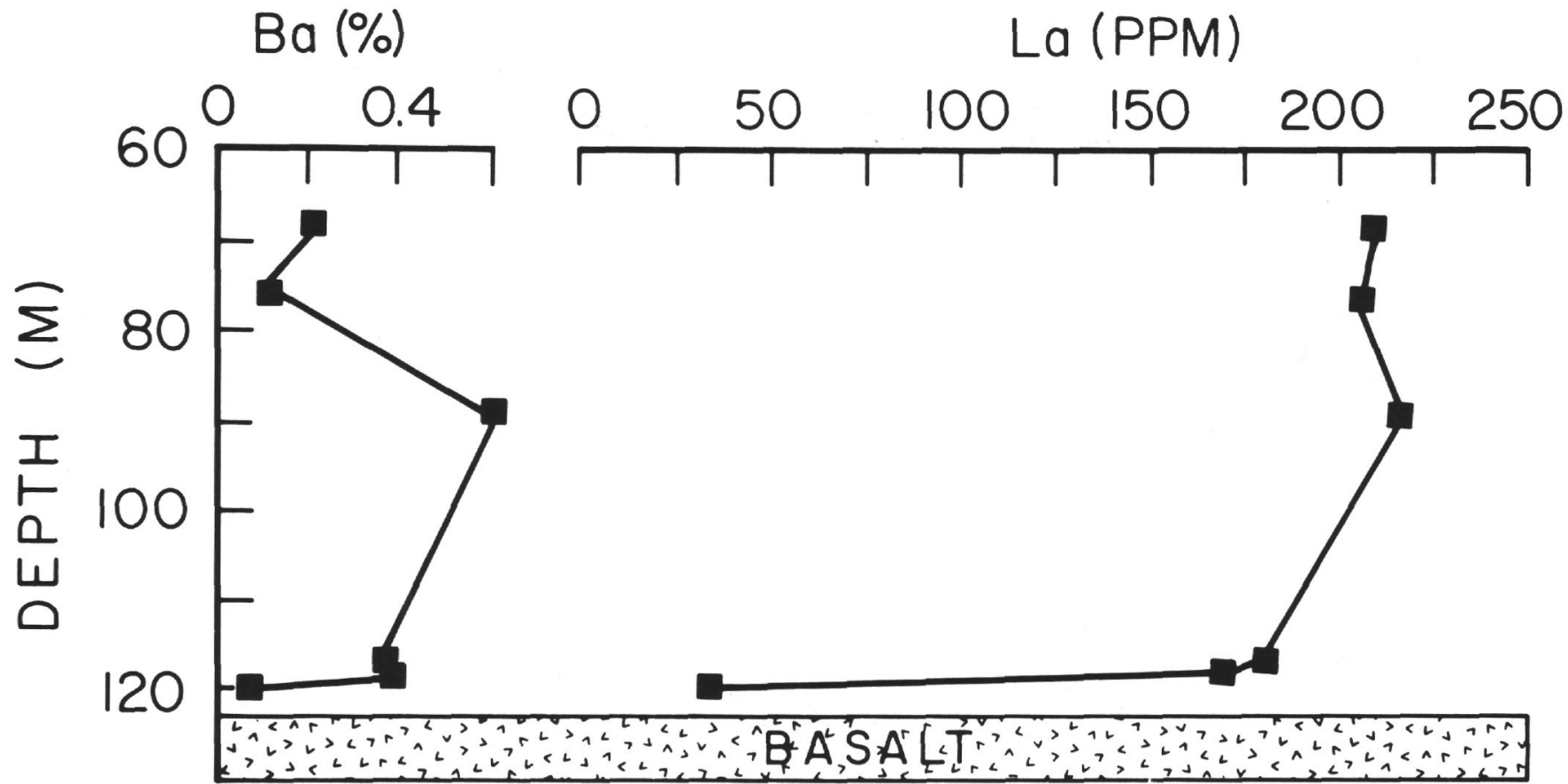

Figure 15. Carbonate and salt corrected sediment composition data for Site 321.

A smooth decrease in metal accumulation is not as evident at this site as it was at Site 319 . This may result from a smaller influence of authigenic sedimentation in this location as a result of the greater proximity to South America and the absence of the Galapagos Rise as a barrier to bottom-transported sediments.

\section{ACKNOWLEDGMENTS}

This work was supported by the National Science Foundation as a contribution to the International Decade of Ocean Exploration (Nazca Plate Project). We thank Magdalena Catalfoma and Carlos Lopez for help with the analyses.

\section{REFERENCES}

Anderson, R. N. and Halunen, A.J., 1974. Implications of heat flow for metallogenesis in the Bauer Deep: Nature, v. 251, p. 473-475.
Bender, M.L., Ku, T.L., and Broecker, W.S., 1970. Accumulation rates of manganese in pelagic sediments and nodules: Earth Planet. Sci. Lett., v. 8, p. 143-148.

Bender, M., Broecker, W., Gornitz, V., Middel, U., Kay, R., Sun, S.S., and Biscaye, P., 1971. Geochemistry of three cores from the East Pacific Rise: Earth Planet. Sci. Lett., v. 12 , p. $425-433$.

Bischoff, J. and Sayles, F., 1972. Pore fluid and mineralogical studies of recent marine sediments, Bauer Depression region of the East Pacific Rise: J. Sediment Petrol., v. 42, p. 711 .

Bonatti, E. and Joensuu, O., 1966. Deep-sea iron deposits from the South Pacific: Science, v. 154, p. 643-645.

Boström, K., 1970. Submarine volcanism as a source for iron: Earth Planet. Sci. Lett., v. 9, p. 348-354.

1973. The origin and fate of ferromanganoan active ridge sediments: Stockholm Contrib. Geol., v. 27, p. 149243 . 
Brewer, P.G. and Spencer, D.W., 1969. A note in the chemical composition of the Red Sea brines. In Degens, E.T. and Ross, D.A. (Eds.), Hot brines and recent heavy metal deposits in the Red Sea: New York (Pringer-Verlag, Inc.), p. 174-179.

Corliss, J.B., 1971. The origin of metal-bearing hydrothermal solutions: J. Geophys. Res., v. 76, p. 8128-8138.

Dasch, E.J., Dymond, J., and Heath, G.R., 1971. Isotopic analysis of metalliferous sediments from the East Pacific Rise: Earth Planet. Sci. Lett., v. 13, p. 175-180.

Dymond, J. and Veeh, H.H., in press. Metal accumulation rates in the southeast Pacific and the origin of metalliferous sediments: Earth Planet. Sci. Lett.

Dymond, J., Corli-s, J.B., Heath, G.R., Field, C.W., Dasch, E.J., and Vees, H.H., 1973. Origin of metalliferous sediments from the Pacific Ocean: Geol. Soc. Am. Bull., v. 84, p. 3355-3372.

Eklund, W.A., 1973. A microprobe study of metalliferous sediment components: M.S. Thesis, Oregon State University, Corvallis.

Garrels, R.M. and Christ, C.L., 1965. Solutions, minerals and equilibria: New York (Harper and Row).

Haskin, L.A., Haskin, M.A., Frey, F.A., and Wildeman, T.R., 1967. Relative and absolute terrestrial abundances of the rare earths: Internat. Assoc. Geochem. Cosmochem., 1 st, Paris.

Hogdahl, O.T., Melson, S., and Bowen, V.T., 1968. Neutron activation analysis of lanthanide elements in seawater: Am. Chem. Soc., Adv. Chem. Ser. No. 73, p. 308-325.

Jones, M.M. and Pytkowicz, R.M., 1973. Solubility of silica in sea water at high pressures: Liege Soc. Roy. Sci., v. 42, p. $125-127$.
Kendrick, J.W., 1973. Trace metal studies of metalliferous sediments in cores from the East Pacific Rise and Bauer Deep, $10^{\circ} \mathrm{S}$ : M.S. Thesis, Oregon State University, Corvallis.

Melson, W.G., Thompson, G., and van Andel, Tj. H., 1968. Volcanism and metamorphism in the Mid-Atlantic Ridge, $22^{\circ} \mathrm{N}$ lat: J. Geophys. Res., v. 73, p. 5925-5941.

Morey, G.W., Fournier, R.O., and Rowe, J.J., 1962. The solubility of quartz in water in the temperature interval $25^{\circ}$ to $300^{\circ} \mathrm{C}$ : Geochim. Cosmochim. Acta, v. 26, p. 1029.

Piper, D.Z., Veeh, H.H., Bertrand, W.G., and Chase, R.L., in press. An iron-rich deposit from the Northeast Pacific: Earth Planet. Sci. Lett.

Pourbaix, M., DeZoubov, N., and Muylder, J., 1963. Altas d'equilibres electrochimiques: Paris (Gauthier-Villars and Cie).

Rea, D., in preparation. An analysis of a fast-spreading rise crest: the East Pacific Rise, $9^{\circ}$ to $12^{\circ}$ South.

Scott, M.R., Scott, R.B., Rona, P.A., Butler, L.W., and Nalwalk, A.J., 1974. Rapidly accumulating manganese deposit from the median valley of the Mid-Atlantic Ridge: Geophys. Res. Lett., v. 1, p. 355-358.

Tomasson, J. and Kristmannsdottir, H., 1972. High temperature alteration minerals and thermal brines, Reykjanes, Iceland: Contrib. Mineral. Petrol., v. 36, p. 123-134.

Veeh, H.H. and Boström, K., 1971. Anomalous ${ }^{234} \mathrm{U} /{ }^{238} \mathrm{U}$ on the East Pacific Rise: Earth Planet. Sci. Lett., v. 10, p. 372374. 